\title{
Holoprosencephaly Type 5
}

National Cancer Institute

\section{Source}

National Cancer Institute. Holoprosencephaly Type 5. NCI Thesaurus. Code C75460.

Holoprosencephaly associated with mutations in the ZIC2 gene. 